Bangladesh J. Plant Taxon. 24(1): 53-63, 2017 (June)

(C) 2017 Bangladesh Association of Plant Taxonomists

\title{
FOLIAR EPIDERMAL, STEM AND PETIOLE ANATOMY OF MEGHALAYAN DIOSCOREA L. (DIOSCOREACEAE) AND ITS SYSTEMATIC IMPLICATION
}

\author{
NiLOFER SHEIKH ${ }^{1}$ AND Yogendra Kumar \\ Botany Department, North Eastern Hill University, Shillong-22, India
}

Keywords: Anatomy; Dioscorea ; Cluster Analysis; Principal Component Analysis; Systematics.

\begin{abstract}
A comparative anatomical study of eight species of Dioscorea L. from Meghalaya, North East India was carried out in order to evaluate the taxonomic significance of anatomical characters to differentiate the species. Characters were coded and analyzed by PCA and cluster analysis. The combination of selected qualitative and quantitative anatomical characters of foliar epidermis, stem and petiole were significant for identification of species. The characters that contributed most to the separation of the species were type of stomata, length of stomata, stomatal index, leaf epidermal hairs, stem epidermal hairs, layer of stem sclerenchyma, number of vascular bundle in outer ring and inner ring of stem, paired or unpaired metaxylem, presence of phloem at both ends or at one end, presence or absence of starch grain in stem, petiole epidermal hair and presence or absence starch grain and crystal in petiole. An indented dichotomous key based on anatomical characters was constructed to distinguish and identify the species.
\end{abstract}

\section{Introduction}

Dioscorea L., with about 602 species (Coursey, 1967) in the tropical and subtropical regions, regarded as the core genus of the family Dioscoreaceae is a pivotal taxon in the evolution of Liliopsida and occupies a basal position among all extant monocotyledonous plants (Chase et al., 2006; Dahlgren, 1989). About 50 species of Dioscorea in India (Anonymous, 1952) and approximately 28 species are distributed in North East India (Sharma and Hore, 1995). Meghalaya, one of the eight hot spots of North East India has wide range of distribution of Dioscorea species in wild habitat. Only a few species of Dioscorea are consumed as food and also used as medicines by the indigenous people of this area in spite of its wide range of distribution. Identification of Dioscorea species has always presented a challenge to taxonomists due to its morphological diversity, dioecy and small flowers. Kunth (1924) divided Dioscorea into four subgenera based on seed morphology. Burkill (1960) divided the genus into 23 sections based on seed characters, tuber characters and male inflorescence morphology. Coursey (1967) divided the genus into 70 sections based on underground tuber. Several authors studied the floristics of the genus including Miege (1968), Milne-Redhead (1975), N'Kounkou (1993), Tellez and Schubert (1994), Miege and Sebsebe (1998) and Ding and Gilbert (2000).

Morphological approaches provide a workable system of taxonomy, yet it cannot be denied that data from other field like anatomy, cytology, palynology, molecular studies etc., provide evidences for the accurate delimitation of the species. Anatomical parameters play an important role in plant taxonomy (Metcalfe and Chalk, 1957). Anatomical characters have proved to be more useful for delimitation of higher taxonomic ranks, such as genera and families. Few researchers studied foliar epidermal anatomy of different species of Dioscorea (Abdulrahman et al., 2009;

${ }^{1}$ Corresponding author. Email: nilofersheikh83@gmail.com

DOI: http://dx.doi.org/10.3329/bjpt.v24i1.33033 
Aina and Atumeyi, 2011; Shah and Gopal, 1972), however, no concrete data of anatomical analysis used in taxonomic delimitation of this genus have been conducted earlier. Therefore, in the present study an attempt has been made to investigate the anatomical features of foliar epidermis, stem and petiole of different species of Meghalayan Dioscorea and to single out distinctive anatomical characters potentially useful for infrageneric classification.

\section{Materials and Methods \\ Plant material}

Fresh material of eight species of Dioscorea viz., D. pentaphylla L. (NEHU-11946), D. alata L. (NEHU-11944), D. belophylla (Prain) Haines (NEHU-11950), D. glabra Roxb. (NEHU11937), D. pubera Bl. (NEHU-11949), D. oppositifolia L. (NEHU-11941), D. lepcharum Prain et Burk. (NEHU-11942) and D. bulbifera L. (NEHU-11935) were collected from wild habitats of Meghalaya. Voucher specimens were deposited in the Herbarium of Botany Department, North Eastern Hill University, Shillong.

\section{Foliar epidermal anatomy}

For foliar epidermal study, fresh leaf epidermal peelings from both the surfaces (adaxial and abaxial) and transverse section of the leaves for epidermal study were made by hand with the help of sharp razor and forceps. Ten individual per species were studied. The epidermal peelings and the transverse section of the leaves were cut into suitable size, taken on a clean slide, stained with $5 \%$ aqueous safranine, mounted in 50\% glycerin and sealed the margins of cover slips with DPX. The prepared slides were observed under a light microscope at $\mathrm{x} 40$ magnification and photographs were taken. To calculate the stomatal index, following formula was used:

$$
\mathrm{I}=5 / E+S \times 100
$$

Where $\mathrm{I}=$ stomatal index, $\mathrm{S}=$ number of stomata per unit area, and $\mathrm{E}=$ number of epidermal cells per unit area. The terminology adopted by Metcalfe and Chalk (1950) and Metcalfe (1961) was followed to describe the stomatal types.

\section{Stem and petiole anatomy}

For the anatomical study of stem and petiole, transverse section of stem and petiole of 10 individual plants per species were made using sharp blade from the fresh material. Temporary slides were prepared following O‘Brien et al. (1964) using Toluidine blue. The stained sections were observed under a light microscope at x10 magnification and Photographed. Presence and absence of starch grain in stem and petiole was separately analyzed by Lugol's solution (Jensen, 1962). The anatomical characters observed under microscopes were recorded.

\section{Anatomical data recording and statistical analysis}

A total of 27 characters including both qualitative and quantitative were observed (Table 1). The characters or traits that appeared in more than one state and differed among the examined species were coded and assessed through principal component analysis (PCA). Cluster analysis (CA) was also performed in order to group the species based on the similarity of anatomical characters or traits. Both PCA and CA were performed using XLSTAT ver. 2015.4.01.22283 statistical software. 
Table 1. List of anatomical characters of stomata, stem and petiole of different Dioscorea species.

\begin{tabular}{|c|c|c|c|}
\hline $\begin{array}{l}\text { Serial } \\
\text { No. }\end{array}$ & $\begin{array}{l}\text { Traits } \\
\text { acronym }\end{array}$ & Characters/ descriptors & Score code-descriptor code \\
\hline & & Stomata & \\
\hline 1 & PAR & Absence/ presence of paracytic & Absent- 0 ; present-1 \\
\hline 2 & ANS & Absence/ presence of anisocytic & Absent- 0 ; present- 1 \\
\hline 3 & TER & Absence/ presence of tetracyctic & Absent- 0 ; present- 1 \\
\hline 4 & ANA & Absence/presence of anomocytic & Absent- 0 ; present- 1 \\
\hline 5 & Nosto & No of stomata per $\mathrm{mm}^{2}$ & 1-(95-124); 2-(125-154);3-(155-184) \\
\hline 6 & Noepi & No of epidermal cell per $\mathrm{mm}^{2}$ & $1-(36-45) ; 2-(46-55) ; 3-(56-65) ; 0->65$ \\
\hline 7 & EpiH & Epidermal hairs & 0-absent; 1-present \\
\hline 8 & Stol & Stomatal index $(\%)$ & $1-(10-15.5) ; 2-(16-20.5) ; 3-(21-25.5)$ \\
\hline 9 & Lsto & Length of stomata $(\mu \mathrm{m})$ & $1-(21-30 \mu \mathrm{m}) ; 2-(31-40 \mu \mathrm{m}) ; 3->40 \mu \mathrm{m}$ \\
\hline \multirow[t]{2}{*}{10} & Bsto & Breadth of stomata $(\mu \mathrm{m})$ & $1-(1-1.4 \mu \mathrm{m}) ; 2-(1.5-1.9 \mu \mathrm{m}) ; 3-(2-2.4 \mu \mathrm{m})$ \\
\hline & & Stem & \\
\hline 11 & STO & Stem outline & 1-Wavy;2-angular; 3-round \\
\hline 12 & SEpiH & Epidermal hair & 1-present; 0-absent \\
\hline 13 & OR & V.B in outer ring & 1-(6-7 rings);2-(8-9rings);3-(10-11rings) \\
\hline 14 & IR & V.B. in inner ring & 1-(4-5 rings);2-(6-7rings);3-(8-9rings) \\
\hline 15 & $\mathrm{LC}$ & Layer of cortex & 1:-6 layers; $2:-7$ layers \\
\hline 16 & LScl & Layer of sclerenchyma & 1:-4 layers; 2:-5 layers;3:-6 layers \\
\hline 17 & $\mathrm{StG}$ & Stem starch grain & 0-absent; 1-present \\
\hline 18 & Mxl & Metaxylem & 1-paired; 2-unpaired \\
\hline 19 & $\mathrm{Ph}$ & Phloem & 1-both ends; 2 -one ends \\
\hline \multirow[t]{2}{*}{20} & Scr & Stem crystals & 1-present; 0 -absent \\
\hline & & Petiole & \\
\hline 21 & $\mathrm{PO}$ & Petiole outline & 1-pentagonal; 2-round; 3-others \\
\hline 22 & PepiH & Petiole epidermal hair & 0-absent; 1-present \\
\hline 23 & Pcol & Petiole cortical layer & 1:-3 layers; $2:-4$ layers; $3:-5$ layers \\
\hline 24 & PSL & Petiole scherenchyma layer & 1:-3 layers; $2:-4$ layers; $3:-5$ layers \\
\hline 25 & V.B. & vascular bundle & 1-6V.B.; 2-8V.B.; 3- 9 V.B. \\
\hline 26 & Pcr & Petiole crystals & 0 -absent; 1 -present \\
\hline 27 & Pst & Petiole starch grain & 0 -absent; 1 -present \\
\hline
\end{tabular}

$* \mu \mathrm{m}=$ micrometer.

\section{Results}

\section{Foliar epidermal anatomy}

The upper (adaxial) and lower (abaxial) epidermis has one layer of cells and each is covered by a cuticle. The outer epidermis is also characterized by the presence of hairs in some species. Stomata are restricted only to the lower surface (hypostomatic). Four types of stomata complex were identified namely anamocytic, tetracytic, paracytic and anisocytic (Fig. 1). D. alata possessed anisocytic, anamocytic and tetracytic stomata; D. pubera possessed paracytic and tetracytic stomata; D. belophylla, D. pentaphylla and D. bulbifera had paracytic, anisocytic and anamocytic types of stomata; $D$. glabra with anamocytic and tetracytic stomata; D. lepcharum and 
D. oppositifolia possessed all the four types of stomata. In the present analysis, the stomatal index ranges from 15.3 in D. alata to 24.6 in D. bulbifera.

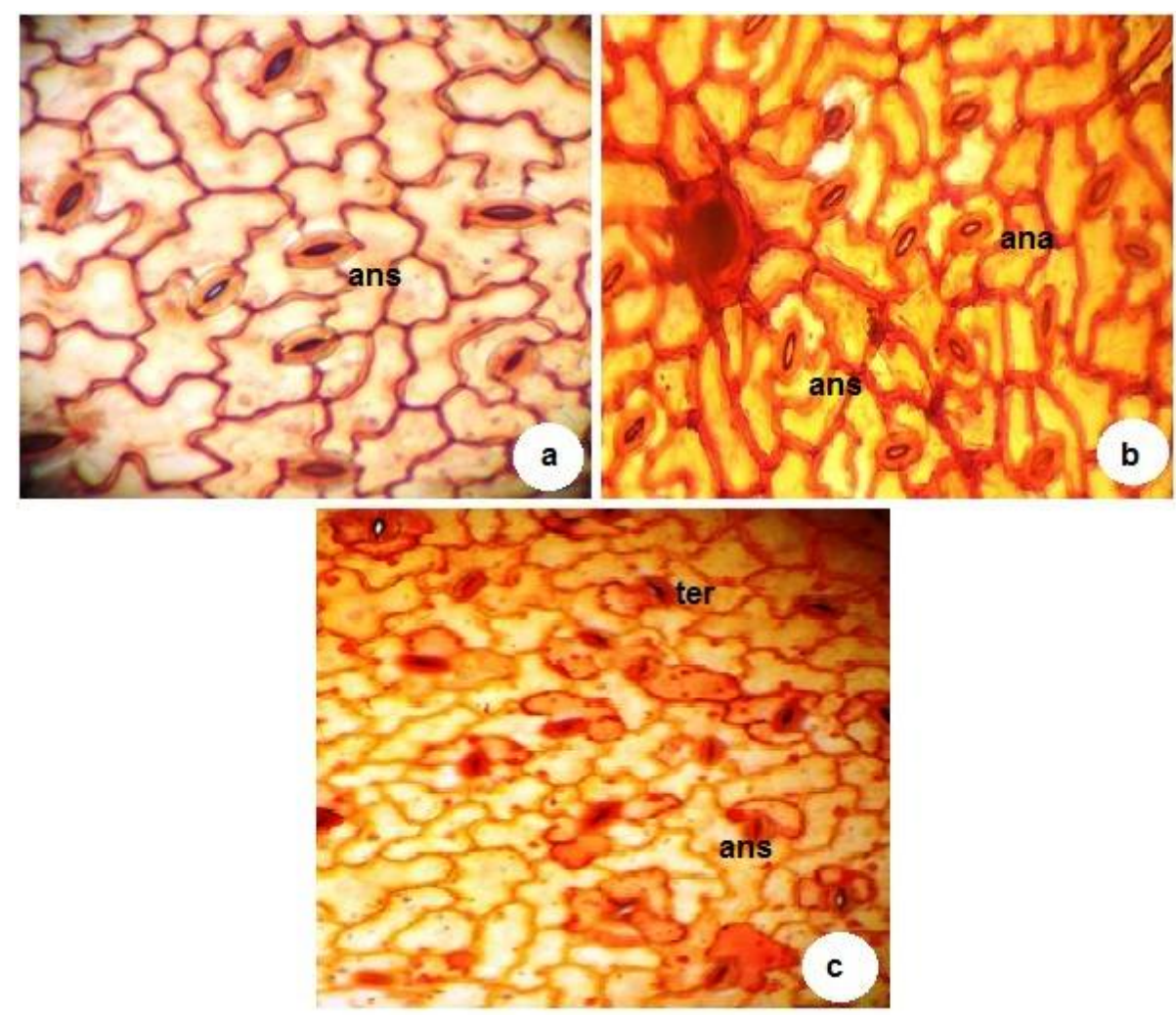

Fig.1. Foliar epidermal structures of Dioscorea species. a) D.bulbifera, b) D. pubera, c) D. alata. (ana anomocytic stomata, ans - anisocytic stomata, ter - tetracytic stomata).

\section{Stem anatomy}

Transverse sections of stems are generally circular with longitudinal ridges or wings (Fig. 2). The epidermis consists of thin-walled rectangular, cuboidal or rounded cells. The epidermal cells are 1-cell layer thick. The cuticle is generally thin. In D. pubera some epidermal cells contained numerous hairs. The cortex lying just beneath the epidermis is composed of 3-7 layers of cells. The cortical cells are of various size and shapes. The inner boundary of cortex is located at a zone of sclerenchyma with 2-many cells. The pith occupies the central position and composed of thinwall hexagonal parenchyma cells. The vascular bundles of the stem are arranged in two concentric circles. The vascular bundles of the outer circle are smaller than the inner, with 2 metaxylem vessels together with 1 phloem unit at the middle in the bundles. The bundles of inner circle have mostly paired metaxylem vessels with phloem unit present at both ends in all species except but in D. bulbifera, where the bundles of inner circle have unpaired metaxylem with phloem unit at one end. The number of vascular bundles in transverse section varies within the species. 


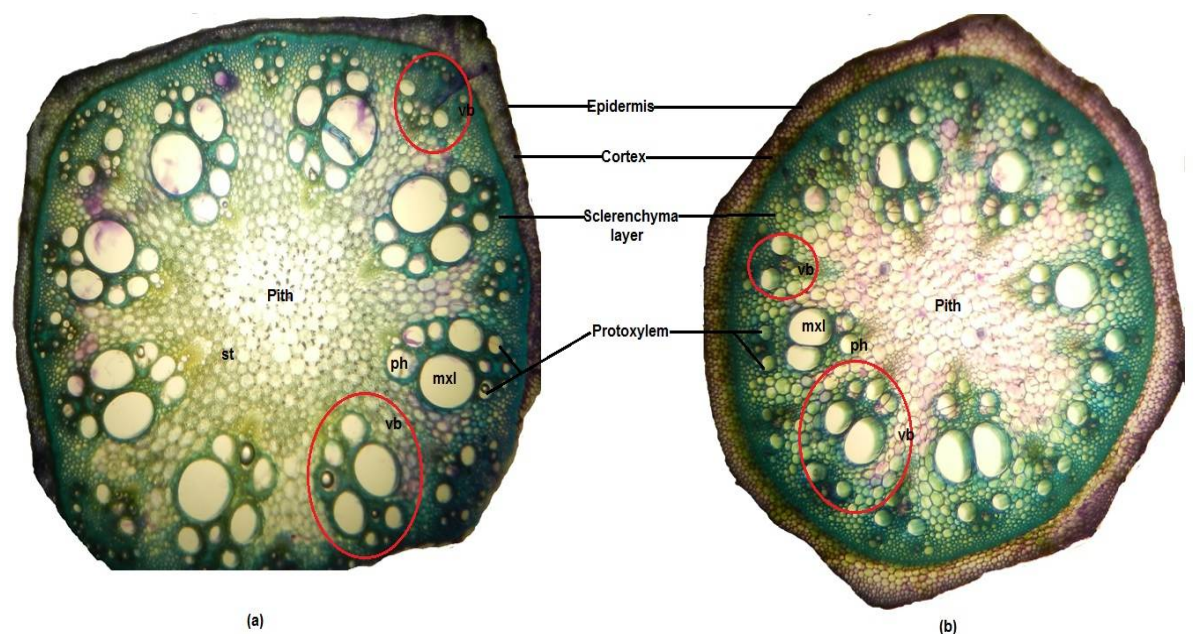

Fig. 2. Anatomy of the stem of Dioscorea species at $4 \mathrm{X}$ magnification. a) D.alata, b) D.belophylla. (st starch grains, $p h$ - phloem, $m x l$ - metaxylem, $v b$ - vascular bundle).

\section{Petioles anatomy}

The cortex is composed of collenchymatous tissues. The vascular bundles are arranged in a ring and are basically collateral with the presences of 2-3 phloem units in each bundle. The number of vascular bundles in each petiole is also variable but constant in each species (Fig. 3).
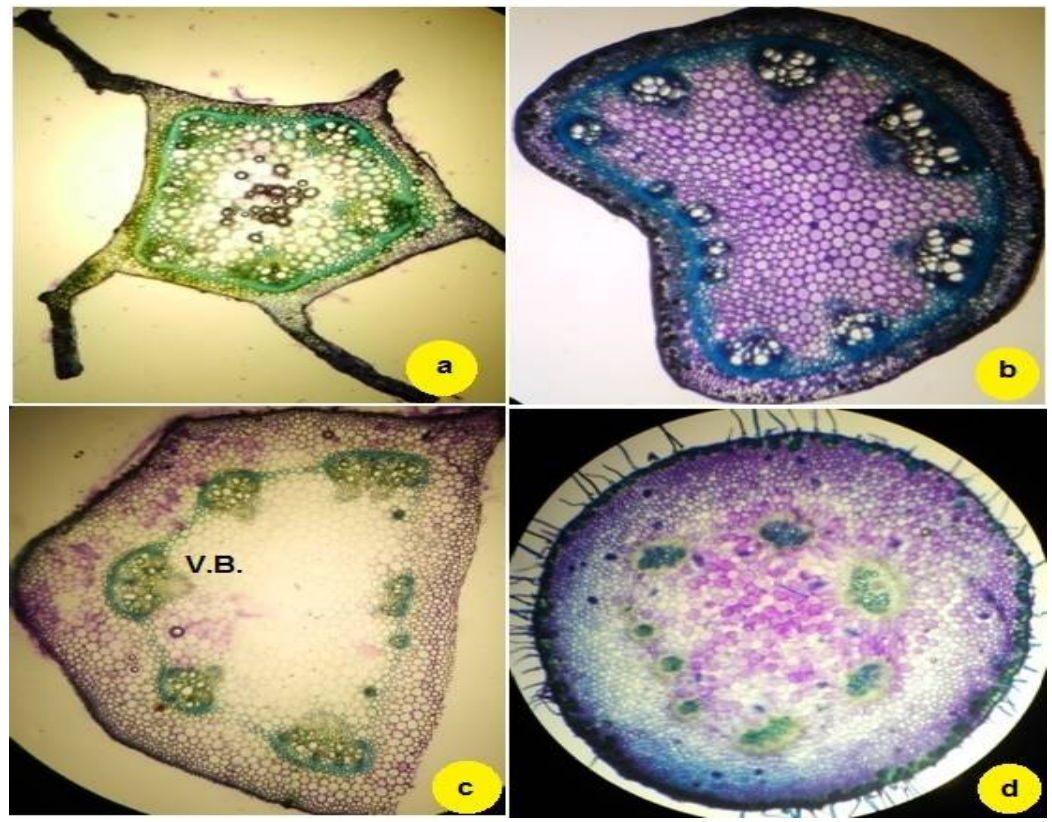

Fig.3. Anatomy of the petiole of Dioscorea species at $4 \mathrm{X}$ magnification. a) D.alata, b) D. lepcharum, c D. belophylla, d) D. pubera.(V.B. vascular bundle). 


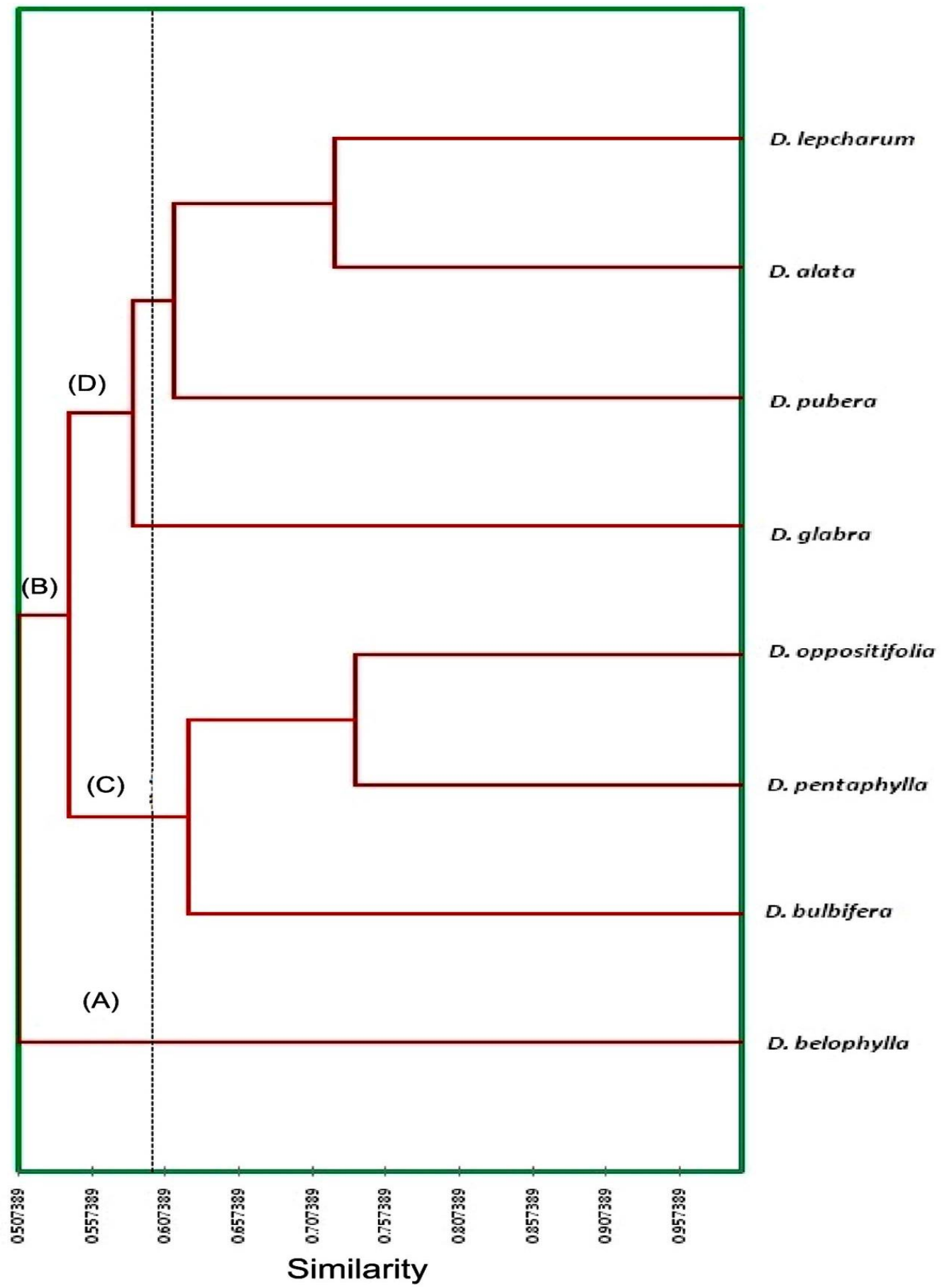

Fig.4. Dendrogram showing relationships among eight Dioscorea species based on anatomical characters. 


\section{Cluster analysis}

The result of cluster analysis based on unweighted pair group average method (UPGMA) initially produced two main clusters, cluster A with a single species $D$. belophylla and the other cluster B at 0.507 level of similarity (Fig. 4). Within the cluster B, two subcluster C and D are separated at similarity level of 0.54 . Subcluster $C$ with $D$. bulbifera is separated from $D$. pentaphylla and D. oppositifolia. D. pentaphylla and D. oppositifolia forms a clade at 0.74 level of similarity. Similarly, subcluster D with D. glabra and D. pubera are separated from D. alata and D. lepcharum which forms a clade at 0.72 level of similarity.

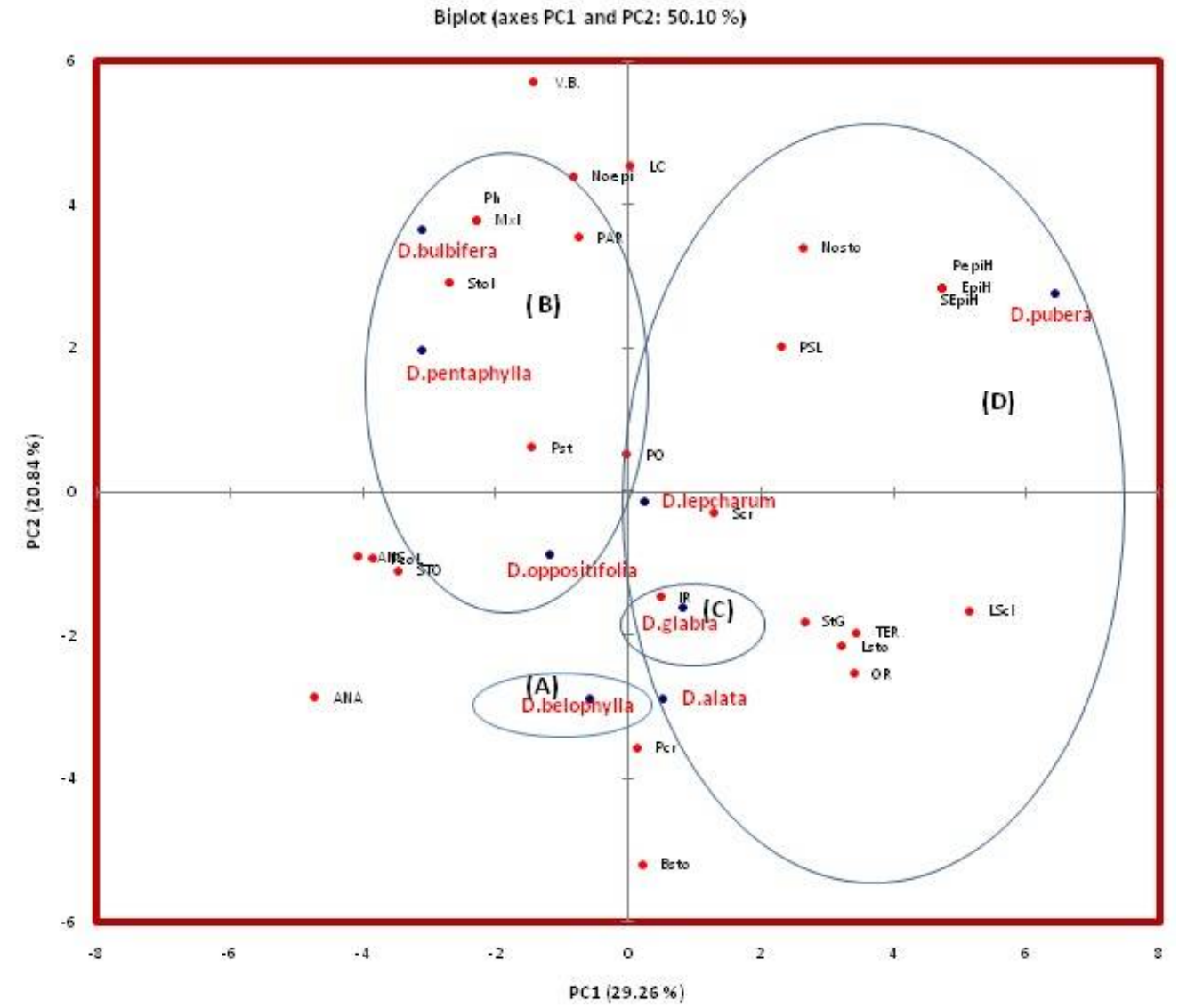

Fig. 5. A biplot based on first and second principal components of anatomical characters for eight Dioscorea species.

\section{Principal component analysis}

The first seven principal components explained about $100 \%$ of the variation, while the first component (PC1) alone counted for $29.26 \%$ of the variability (Table 2). Characters such as tetracytic type of stomata, presence or absence of leaf epidermal hair, length of stomata, presence of stem epidermal hair, number of vascular bundle present in outer ring of stem, number of schlerenchyma of in stem, presence of epidermal hair in petioles has the highest loading on PC1. The second component (PC2) explained $20.84 \%$ of the total variation was highly correlated with paracytic type of stomata, number of stomata, layers of cortex in stem, presence of paired or 
unpaired metaxylem in stem, presence of phloem at one end or at both ends and number of vascular bundles in petioles. The remaining component explained less variability. To assess the scores of the individual species with its characters or traits, PC1 and PC2 were plotted (Fig. 5). The group of species on the left side of the biplot is separated from the species on the right side of biplot due to certain combination of anatomical characters, viz., anamocytic and paraytic types of stomata, presence of starch in petiole, number of vascular bundle in petiole, presence of metaxylem paired or unpaired in stem, presence of phloem at one end or at both ends in stem,

Table 2. Eigenvalues, variance, cumulative variance and component scores (eigenvectors) of the first 7 principal components (PC) for anatomical characters of Dioscorea species.

\begin{tabular}{|c|c|c|c|c|c|c|c|}
\hline \multicolumn{8}{|c|}{ Component scores } \\
\hline & $\mathrm{PC} 1$ & $\mathrm{PC} 2$ & PC3 & $\mathrm{PC} 4$ & PC5 & PC6 & PC7 \\
\hline Eigenvalue & 7.900 & 5.626 & 4.836 & 3.554 & 2.746 & 1.372 & 0.965 \\
\hline Variance (\%) & 29.260 & 20.836 & 17.912 & 13.162 & 10.171 & 5.083 & 3.576 \\
\hline Cumulative \% & 29.260 & 50.096 & 68.008 & 81.170 & 91.341 & 96.424 & 100.000 \\
\hline PAR & -0.138 & 0.548 & -0.090 & -0.734 & 0.078 & 0.270 & -0.236 \\
\hline ANS & -0.742 & -0.138 & -0.471 & -0.360 & -0.275 & 0.043 & -0.042 \\
\hline ANA & -0.863 & -0.439 & 0.043 & 0.175 & -0.109 & 0.056 & -0.124 \\
\hline TER & 0.625 & -0.302 & 0.169 & 0.274 & -0.522 & 0.349 & 0.143 \\
\hline Nosto & 0.483 & 0.525 & 0.500 & 0.400 & 0.094 & -0.138 & -0.231 \\
\hline Noepi & -0.150 & 0.678 & 0.437 & 0.518 & -0.131 & -0.187 & -0.081 \\
\hline EpiH & 0.863 & 0.439 & -0.043 & -0.175 & 0.109 & -0.056 & 0.124 \\
\hline StoI & -0.493 & 0.450 & 0.147 & -0.357 & 0.559 & -0.079 & -0.294 \\
\hline Lsto & 0.586 & -0.331 & -0.530 & -0.259 & -0.142 & -0.197 & -0.373 \\
\hline Bsto & 0.041 & -0.799 & 0.371 & 0.379 & 0.013 & 0.237 & -0.147 \\
\hline STO & -0.634 & -0.169 & -0.091 & -0.583 & 0.217 & -0.062 & 0.413 \\
\hline SEpiH & 0.863 & 0.439 & -0.043 & -0.175 & 0.109 & -0.056 & 0.124 \\
\hline OR & 0.619 & -0.389 & -0.566 & -0.027 & -0.017 & 0.161 & -0.343 \\
\hline IR & 0.089 & -0.225 & -0.351 & 0.848 & 0.187 & 0.249 & 0.047 \\
\hline LC & 0.006 & 0.701 & 0.571 & 0.116 & -0.224 & 0.341 & -0.052 \\
\hline LScl & 0.937 & -0.255 & -0.002 & -0.132 & -0.005 & 0.200 & 0.013 \\
\hline $\mathrm{StG}$ & 0.484 & -0.278 & 0.392 & -0.207 & 0.564 & 0.374 & 0.183 \\
\hline Mxl & -0.418 & 0.584 & -0.430 & 0.400 & 0.297 & 0.217 & -0.057 \\
\hline $\mathrm{Ph}$ & -0.418 & 0.584 & -0.430 & 0.400 & 0.297 & 0.217 & -0.057 \\
\hline Scr & 0.236 & -0.044 & -0.802 & -0.238 & -0.055 & 0.486 & -0.068 \\
\hline $\mathrm{PO}$ & -0.003 & 0.081 & 0.856 & -0.114 & -0.459 & 0.184 & -0.052 \\
\hline PepiH & 0.863 & 0.439 & -0.043 & -0.175 & 0.109 & -0.056 & 0.124 \\
\hline PcoL & -0.704 & -0.143 & 0.303 & -0.272 & -0.529 & 0.171 & -0.095 \\
\hline PSL & 0.419 & 0.312 & -0.470 & 0.081 & -0.613 & -0.316 & -0.155 \\
\hline V.B. & -0.259 & 0.880 & -0.171 & -0.047 & -0.124 & 0.332 & -0.028 \\
\hline Pcr & 0.022 & -0.548 & 0.346 & 0.138 & 0.686 & -0.071 & -0.290 \\
\hline Pst & -0.265 & 0.096 & -0.742 & 0.545 & -0.044 & -0.104 & 0.246 \\
\hline
\end{tabular}

Coefficient in bold indicate descriptors that are highly correlated with the corresponding principal component. 
whereas species on the right side of the plot is represented with characters such as presence of foliar epidermal, stem epidermal and petiole epidermal hairs, number of petiole schlerenchyma layers, number of stomata per unit area etc. The finding was consistent with the separation of species into four major groups by UPGMA clustering (Fig. 4).

\section{Discussion}

The use of anatomical characters or traits for taxonomic studies has proved useful for identification of fragmented plant and herbarium specimens (Metcalfe and Chalk, 1957). Anatomy can provide useful information for establishing interrelations between taxa at the species and supra species levels. Sometimes it can also help in individual identifications. The internal structure of leaf is more affected by environmental factors and thus is of little value for delimiting taxonomic groups. Other characters of leaf, such as the epidermis and stomata have proved to be much more reliable for taxonomic consideration in many genera (Uphof, 1962; Dickison, 2000; Yang and Lin, 2005; Strgulc-Krajsek et al., 2006). The petiole structure is of considerable taxonomic importance in many genera, since it is less affected by environmental changes (Metcalfe and Chalk, 1957). The result of the present study allows the selection of some diagnostic anatomical characters for the identification of Meghalayan Dioscorea species. Stebbin and Khush (1961) and Ayensu (1972) reported that all stomata in Dioscorea species were anomocytic which was found in consistent with Shah and Gopal (1972) and Abdulrahaman et al. (2009). Our results showing presence of different types of stomata including paracytic, tetracytic and anomocytic etc were found congruent with those of Shah and Gopal (1972) and Abdulrahaman et al. (2009). The present study reveals an anamocytic character trait contributes much towards variability. Presence of starch grain in stem and petiole is also an important character trait for differentiating among the species (Onwuene, 1978). From the PCA analysis, the character trait i.e. presence of starch grain in petiole was another important trait which shows high rate of variability. Hence the foregoing analysis and presented illustration clearly show the importance of anatomical data as an additional tool in the taxonomy of the genus and also contributes to the identification of species. The results provided some useful features for future phylogenetic and taxonomic studies. Based on these features, an artificial indented dichotomous key is presented hereunder to delimit the species.

\section{Dichotomous key to the Meghalayan species of Dioscorea based on anatomical characters.}

1. Leaf, stem and petiole pubescent

- Leaf, stem and petiole glabrous

2. Absence of tetracytic stomata

- Presence of tetracytic stomata

3. Layer of schlerenchyma in stem is more than 5; absence of starch grain in stem; vascular bundle in outer ring in stem is more than 9

- Layer of schlerenchyma in stem is less than 5; presence of starch grain in stem; vascular bundle in outer ring in stem is less than 9

4. Inner ring of vascular bundle in stem is less than 6; metaxylem in stem is paired; phloem on both ends of vascular bundle

- Inner ring of vascular bundle in stem is more than 6; metaxylem unpaired; phloem at one end of vascular bundle

\section{D. pubera}

2

3

5

D. belophylla

4

D. pentaphylla

D. bulbifera 
5. Presence of starch grain in stem; outer ring of vascular bundle more than 9

- Absence of starch grain in stem; outer ring of vascular bundle less than 9

6. Inner ring of vascular bundle more than 9; petiole outline mainly pentagonal; layer of cortex in petiole less than 4

D. alata

- Inner ring of vascular bundle less than 9, petiole outline crescent shape; layer of cortex in petiole more than 4

\section{D. lepcharum}

7. Inner ring of vascular bundle in stem less than 8; presence of paracytic stomata; absence of petiole crystal, layer of cortex in petiole is more than 4

- Inner ring of vascular bundle more than 8; absence of paracytic stomata; presence of petiole crystal, layer of cortex in petiole is less than 4

\section{D. oppositifolia}

\section{D.glabra}

\section{Acknowledgements}

The authors are thankful to the Head of Botany Department, North Eastern Hill University, Shillong for providing the facilities in the department and also to UGC for providing financial support under the scheme of Maulana Azad minority national fellowship. Our sincere thanks to the Joint Director, Botanical Survey of India eastern circle, Shillong for giving us the facilities during the tenure of this research programme.

\section{References}

Abdulrahaman, A.A., Egbedo, F.O. and Oladele, F.A. 2009. Stomatal complex types, stomatal density and the stomatal index in some species of Dioscorea. Arch. Biol. Sci., Belgrade 61(4): 847-851.

Aina, O.D. and Atumeyi, S. 2011. Foliar epidermal anatomy of four species of Dioscorea. Advances Appl. Sci. Res. 2(4): 21-24.

Anonymous, 1952. The Wealth of India. Vol. 3. D-E, CSIR, New Delhi.

Ayensu, E.S. 1972. Dioscoreales. In: Metcalfe, C. (Ed.), Anatomy of the Monocotyledons. Vol. 6. Clarendon Press, Oxford, pp. 1-182.

Burkill, I.H. 1960. The organography and the evolution of the Dioscoreaceae, the family of the yams. Bot. J. Linn. Soc. 56: 319-412.

Chase, M.W., Fay, M.F., Devey, D.S., Maurin, O., Ronsted, N., Davies, T.J., Pillon,Y., Petersen, G., Seberg, O., Tamura, M.N., Asmussen, C.B., Hilu, K., Borsch, T., Davis, J.I., Stvenson, D.W., Pires, J.C., Givnish, T.J., Sytsma, T.J., McPherson, M.A., Graham, S.W. and Rai, H.S. 2006. Multigene analysis of monocot relationships, a summary. Aliso 22: 63-75.

Coursey, D.G. 1967. Yams: An account of the nature, origins, cultivation and utilization of the useful members of the Dioscoreaceae: Tropical Agricultural series. Longmans, Green and Co. Ltd., London, $230 \mathrm{pp}$.

Dahlgren, G. 1989. An undated angiosperm classification. Bot. J. Linn. Soc. 100: 197-203.

Ding, Z. and G ilbert, M.G. 2000. Dioscoreaceae. In: Wu, Z. and Raven, P.H. (Eds), Flora of China. Vol. 24. Flagellariaceae through Marantaceae. Science Press: Beijing, and Missouri Botanical Garden Press, St. Louis, pp. 276-296.

Dickison, W.C. 2000. Integrative Plant Anatomy. Academic Press, San Diego.

Jensen, W.A. 1962. Botanical Histochemistry: Principles and Practice. San Francisco: W.H. Freeman \& Company.

Kunth, R. 1924. Dioscoreaceae. In: Engler, H.G.A. (Ed) Das Pflanzenreich, 87(IV. 43). Leipzig: H. R. Engelmann (J.Cramer). pp. 1-387. 
Metcalfe, C.R. 1961. The anatomical approach to systematics: general introduction with special reference to recent work on monocotyledons. Rec. Adv. Bot. 1: 146-150.

Metcalfe, C.R. and Chalk, L. 1950. Anatomy of Dicotyledons, Vols. $\square$ and $\square$. Clarendon Press, Oxford.

Metcalfe, C.R. and Chalk, L. 1957. Anatomy of the Dicotyledons, Vol I. Clarendon Press, Oxford, pp. 502-535.

Miege, J. 1968. Dioscoreaceae. In: Flora of West Tropical Africa, $2^{\text {nd }}$ ed. F. N. Hepper. London: Crown Agents, pp.144-154.

Miege, J. and Sebsebe, D. 1998. Dioscoreaceae. In: Edwards, S., Sebsebe, D. and Hedberg, I. (Eds), Flora of Ethiopia and Eritrea. Vol. 6. Addis Ababa: The National Herbarium, Biology Department, Science Faculty, Addis Ababa University; Uppsala: Department of Systematic Botany, Uppsala University, pp 55-62.

Milne-Redhead, E. 1975. Dioscoreaceae. In: Polhill, R.M. (Ed), Flora of Tropical East Africa. London. Crown Agents.

N'Kounkou, J.S. 1993. Les Dioscoreaceae du Congo. Fragmenta Floristica Geobotanica, Supplementa 2: $139-182$.

O’Brien, T.P., Feder, N. and Mccully, M.E. 1964. Polychromatic staining of plant cell walls by toluidine blue O. Protoplasma 5(2): 368-373.

Onwueme, I.C. 1978. The Tropical Tuber Crops; Yams, Cassava, Sweet Potato and Cocoyams. John Wiley \& Sons, New York.

Shah, G.L. and Gopal, B.V. 1972. Some six species observations on diversity of stomata and trichomes in Dioscorea (Yams) Ann Bot. (London) 36(148): 997-1004.

Sharma, B.D. and Hore, D.K. 1995. Genetic resource of yams in N.E. India with special reference to Garo Hills, Meghalaya. Indian J. Hill Farming 8: 145-151.

Stebbins, G.L. and Khush, G.S. 1961. Variation in the organization of the stomatal complex in the leaf epidermis of monocotyledons and its bearing on their phylogeny. Ann. J. Bot. 48: 51-90.

Strgulc-Krajsek, S., Dermastia, M. and Jogan, N. 2006. Determination key for Central European Epilobium species based on trichome morphology. Bot. Helv. 116: 169-178.

Tellez, V.O. and Schubert, B.G. 1994. Dioscoreaceae. In: Davidse, G. Sousa, M. and Chater A.O. (Eds). Flora Mesoamericana. Volumen 6. Universidad Nacional Autonoma de Mexico, pp. 54-65.

Uphof, J.C. 1962. Plant Hairs, Encyclopedia of Plant Anatomy IV. Borntraeger, Berlin.

Yang, Z.R. and Lin, Q. 2005. Comparative morphology of the leaf epidermis in Schisandra (Schisandraceae). Bot. J. Linn. Soc. 148: 39-56. 